\title{
The prognostic and predictive power of redox protein expression for anthracycline-based chemotherapy response in locally advanced breast cancer
}

\author{
Caroline M Woolston ${ }^{1}$, Lei Zhang ${ }^{1}$, Sarah J Storr ${ }^{1}$, Ahmad Al-Attar ${ }^{2}$, Mohamed Shehata ${ }^{2}$, \\ Ian O Ellis ${ }^{3}$, Stephen Y Chan ${ }^{2}$ and Stewart G Martin ${ }^{1}$ \\ ${ }^{1}$ Department of Academic Oncology, School of Molecular Medical Sciences, University of Nottingham, \\ Nottingham University Hospitals NHS Trust, City Hospital Campus, Nottingham, UK; ${ }^{2}$ Department of \\ Clinical Oncology, Nottingham University Hospitals NHS Trust, City Hospital, Nottingham, UK and \\ ${ }^{3}$ Department of Histopathology, School of Molecular Medical Sciences, University of Nottingham, \\ Nottingham University Hospitals NHS Trust, City Hospital Campus, Nottingham, UK
}

\begin{abstract}
Neoadjuvant chemotherapy has become the standard of care for locally advanced primary breast cancer. Anthracycline-based regimens have proven to be one of the most effective treatments in this setting. As certain cytotoxic antineoplastic agents, such as anthracyclines, generate reactive oxygen species as a by-product of their mechanism of action, we examined whether redox protein expression was involved in the response to anthracycline-based chemotherapy and with clinical outcome. Pre-treatment needle core biopsy and postanthracycline treatment tumour sections were analysed from 98 cases. In all, 32 individuals had a complete clinical response and 17 had a complete pathological response. Immunohistochemical staining was performed for eight redox proteins: thioredoxin, thioredoxin reductase, thioredoxin interacting protein (TxNIP), glutathione S-transferase (GST) $\pi, \theta$ and $\alpha$, catalase and manganese superoxide dismutase. GST $\pi(P=0.05)$ and catalase $(P=0.045)$ were associated with pathological complete response in pre-chemotherapy samples. TxNIP $(P=0.017)$ and thioredoxin reductase $(P=0.022)$ were independent prognostic factors for distant metastasisfree survival and TXNIP for overall survival $(P=0.014)$. In oestrogen receptor negative patients that are known to have a poor overall survival, a considerably worse prognosis was seen in cases that exhibited low expression of TxNIP $(P=\mathbf{0 . 0 0 0 0 0 3})$, stratifying patients into more defined groups. This study indicates the importance of redox regulation in determining breast cancer response to anthracycline-based chemotherapy and provides ways of further stratifying pre-chemotherapy patients to potentially allow more tailored treatments.
\end{abstract}

Modern Pathology (2012) 25, 1106-1116; doi:10.1038/modpathol.2012.60; published online 6 April 2012

Keywords: anthracycline; breast cancer; chemotherapy; glutathione; redox; thioredoxin interacting protein

Neoadjuvant chemotherapy has become the standard of care for locally advanced primary breast cancer patients and aims to reduce tumour burden, to render tumours operable, or facilitate breast conservation and other oncoplastic options. In this

Correspondence: Dr SG Martin, PhD, Academic Oncology, School of Molecular Medical Sciences, University of Nottingham, Nottingham University Hospitals NHS Trust, City Hospital Campus, Nottingham NG5 1PB, UK.

E-mail: stewart.martin@nottingham.ac.uk

Received 25 November 2011; revised 14 February 2012; accepted 15 February 2012; published online 6 April 2012 setting, anthracycline-based regimens are commonly used. Anthracyclines have a complex mechanism of action including inhibition of enzymes such as topoisomerase II, resulting in DNA double-strand breaks, intercalation into DNA and also generation of reactive oxygen species. ${ }^{1}$ The anthracycline drugs have a quinone that undergoes reduction to a semiquinone-free radical, forming superoxide anions in the presence of oxygen. After dismutation, resultant hydrogen peroxide $\left(\mathrm{H}_{2} \mathrm{O}_{2}\right)$ can be converted into the highly damaging hydroxyl radical. ${ }^{2}$ The semiquinone radical can also intercalate and damage DNA. There are currently no markers to determine 
response to neoadjuvant chemotherapy in locally advanced primary breast cancer.

In cancer, the normal redox balance is disrupted due to increased oxidative stress caused by accelerated cell proliferation, constant stimulation of growth promoting signalling pathways and alterations in metabolic activity. Due to this, redox buffering systems such as the thioredoxin and glutathione systems, and antioxidant enzymes such as catalase and superoxide dismutase are often deregulated/overexpressed to compensate. ${ }^{3-6}$ These processes can add to the oncogenic transformation and mutation rate in tumours and influence their response to reactive oxygen species generating therapies. ${ }^{7,8}$

The current study investigates expression of a panel of redox proteins representing the key pathways: thioredoxin, thioredoxin reductase, thioredoxin interacting protein (TxNIP), glutathione S-transferase (GST) $\pi, \theta, \alpha$, catalase and manganese superoxide dismutase (MnSOD), in a well-defined cohort of pre-treatment locally advanced primary breast cancer patients before anthracycline chemotherapy. Their expression was investigated for response to therapy and aiding prognosis. A postchemotherapy tumour specimen was available from certain patients that allowed a matched comparison of protein expression to be assessed, yielding information on particular redox pathways that are altered in response to chemotherapy.

\section{Materials and methods}

\section{Clinical Samples}

The study is reported according to REMARK criteria. $^{9}$ The consecutive cohort consisted of 98 patients presenting with locally advanced primary breast cancer between December 1996 and December 2009 at Nottingham University Hospitals and treated with neoadjuvant anthracycline-based chemotherapy. The core biopsies from 82 patients were assessed for all redox proteins studied, 16 additional patients were available for assessment of TxNIP only $(n=98)$. A core biopsy was performed before chemotherapy to allow pathological diagnosis and evaluation of biological parameters. Patients were then treated with six cycles of anthracyclinebased therapy (5-fluorouracil (5-FU) $500 \mathrm{mg} / \mathrm{m}^{2}$, epirubicin $\quad 75-100 \mathrm{mg} / \mathrm{m}^{2}$, cyclophosphamide $500 \mathrm{mg} / \mathrm{m}^{2}$, on day 1 of a 21-day cycle). Patients underwent surgery 4 weeks after the sixth cycle, unless progression after three cycles, in which case taxanes were used. All oestrogen receptor positive cases received adjuvant hormonal treatment.

Assessment of tumour response was undertaken before chemotherapy and after each cycle. The clinical baseline and preoperative measurements were obtained with a calliper by the same clinician or by radiological assessment. Clinical response was recorded according to RECIST criteria. ${ }^{10}$
The pathological response was evaluated by histological examination of tumour removed following chemotherapy. For certain cases, whole tumour sections post-chemotherapy were available for redox protein assessment as matched pairs to the prechemotherapy samples (see Results section for numbers). Histology was reviewed using the Chevallier classification. ${ }^{11}$ Ethical approval was obtained from the Nottingham Research Ethics Committee (C202313).

\section{Immunohistochemistry}

Immunohistochemistry was performed on core biopsies and whole tumour sections as previously described. ${ }^{5}$ Briefly, microwave antigen retrieval was conducted in $0.01 \mathrm{~mol} / \mathrm{l}$ sodium citrate buffer ( $\mathrm{pH}$ 6). Primary antibodies were incubated for $60 \mathrm{~min}$ at room temperature (thioredoxin 1:1000 (\#705, American Diagnostica, Stamford, USA), thioredoxin reductase 1:1000 (\#07-613, Millipore, Billerica, USA), TxNIP 1:3000 (clone JY2, MBL International Corporation, Woburn, USA), catalase 1:5000 (\#ab1877, Abcam, Cambridge, UK), MnSOD 1:1000 (\#ab13533, Abcam), GST $\alpha$ (clone 2F7) 1:333, GST $\theta$ (clone 2E10-1B2) 1:500 (Abnova, Taipei City, Taiwan), GST $\pi$ 1:2000 (\#MSA-102, Assay Designs, Michigan, USA)). Blocking, secondary, ABC and 3,3'-diaminobenzidine (DAB) substrate reagents were supplied in kit form from Vector Labs (Vector Laboratories, Burlingame, USA). Primary antibody was omitted for negative controls. Placenta and breast composite blocks (six stage I breast carcinomas, including grade I-III tumours) were used for antibody optimisations and positive controls, with liver sections used for GST $\alpha$. All antibodies had been previously assessed for specificity using western blotting on a panel of breast cancer cell lysates.

Assessment of protein staining was conducted by standard semiquantitative immunohistochemistry scoring ( $\mathrm{H}$ score) conducted independently by two assessors blinded to the study end points. Staining intensity was divided into: none (0), weak (1) moderate (2) and strong (3). $\mathrm{H}$ scores were calculated by multiplying the percentage of positive tumour by the staining intensity (range 0-300). Lowvs high-expressing tumours were determined using median $\mathrm{H}$ scores-thioredoxin 190, thioredoxin reductase 200, TxNIP 160, GST $\theta$ 185, GST $\pi$ 85, catalase 90, MnSOD 175. No tumour staining was observed for GST $\alpha$.

\section{Statistical Analysis}

SPSS version 15.0 software package was used for statistical analysis. Protein expression vs clinicopathological criteria was assessed using the Pearson $\chi^{2}$ test of association or Fisher's exact test when there are less than five cases in a cell. Survival analysis was conducted using Kaplan-Meier and 
Table 1 Clinicopathological criteria of locally advanced primary breast cancer patients who underwent neoadjuvant anthracycline-based chemotherapy

\begin{tabular}{|c|c|c|c|c|c|c|c|c|c|c|c|c|c|c|c|c|c|c|c|c|c|}
\hline & \multicolumn{3}{|c|}{ Thioredoxin } & \multicolumn{3}{|c|}{$\begin{array}{l}\text { Thioredoxin } \\
\text { reductase }\end{array}$} & \multicolumn{3}{|c|}{ TxNIP } & \multicolumn{3}{|c|}{$\begin{array}{c}\text { Glutathione } \\
\text { S-transferase } \pi\end{array}$} & \multicolumn{3}{|c|}{$\begin{array}{c}\text { Glutathione } \\
\text { S-transferase } \theta\end{array}$} & \multicolumn{3}{|c|}{ Catalase } & \multicolumn{3}{|c|}{$\begin{array}{l}\text { Manganese } \\
\text { superoxide }\end{array}$} \\
\hline & $\begin{array}{l}\text { Low } \\
(\%)\end{array}$ & $\begin{array}{c}\text { High } \\
(\%)\end{array}$ & $\mathrm{P}$-value & $\begin{array}{l}\text { Low } \\
(\%)\end{array}$ & $\begin{array}{c}\text { High } \\
(\%)\end{array}$ & $\mathrm{P}$-value & $\begin{array}{l}\text { Low } \\
(\%)\end{array}$ & $\begin{array}{c}\text { High } \\
(\%)\end{array}$ & P-value & $\begin{array}{l}\text { Low } \\
(\%)\end{array}$ & $\begin{array}{c}\mathrm{High} \\
(\%)\end{array}$ & $\mathrm{P}$-value & $\begin{array}{l}\text { Low } \\
(\%)\end{array}$ & $\begin{array}{c}\text { High } \\
(\%)\end{array}$ & P-value & $\begin{array}{l}\text { Low } \\
(\%)\end{array}$ & $\begin{array}{c}\text { High } \\
(\%)\end{array}$ & $\mathrm{P}$-value & $\begin{array}{l}\text { Low } \\
(\%)\end{array}$ & $\begin{array}{c}\text { High } \\
(\%)\end{array}$ & $\mathrm{P}$-value \\
\hline \multicolumn{22}{|l|}{ Age (years) } \\
\hline$\leq 40$ & $10(71)$ & $4(29)$ & 0.217 & $7(47)$ & $8(53)$ & 0.393 & $6(38)$ & $10(62)$ & 0.352 & $7(54)$ & $6(46)$ & 0.747 & $8(67)$ & $4(33)$ & 0.284 & $9(60)$ & $6(40)$ & 0.790 & $7(47)$ & 8 (53) & 0.840 \\
\hline $41-60$ & $20(47)$ & $23(53)$ & & $24(56)$ & $19(44)$ & & $33(58)$ & $24(42)$ & & $19(46)$ & $22(54)$ & & $17(43)$ & $23(57)$ & & $20(50)$ & $20(50)$ & & $22(54)$ & $19(46)$ & \\
\hline$>60$ & $6(43)$ & $8(57)$ & & $10(71)$ & $4(29)$ & & $9(53)$ & $8(47)$ & & $8(57)$ & $6(43)$ & & $8(57)$ & $6(43)$ & & $7(50)$ & $7(50)$ & & $6(46)$ & $7(54)$ & \\
\hline Total & 36 & 35 & & 41 & 31 & & 48 & 42 & & 34 & 34 & & 33 & 33 & & 36 & 33 & & 35 & 34 & \\
\hline \multicolumn{22}{|c|}{ - (-0) } \\
\hline Ductal NST & $35(53)$ & $31(47)$ & $0.170^{*}$ & $38(57)$ & $29(43)$ & $0.632^{*}$ & $43(52)$ & $40(48)$ & $0.276^{*}$ & $33(52)$ & $30(48)$ & $0.178^{*}$ & $30(48)$ & $32(52)$ & $0.307^{*}$ & $34(53)$ & $30(47)$ & $0.458^{*}$ & $33(52)$ & $31(48)$ & $0.486^{*}$ \\
\hline Lobular & $1(20)$ & $4(80)$ & & $3(60)$ & $2(40)$ & & $5(71)$ & $2(29)$ & & $1(20)$ & $4(80)$ & & $3(75)$ & $1(25)$ & & $2(40)$ & $3(60)$ & & $2(40)$ & $3(60)$ & \\
\hline Total & 36 & 35 & & 41 & 31 & & & & & 34 & 34 & & 33 & 33 & & 36 & 33 & & 35 & 34 & \\
\hline \multicolumn{22}{|l|}{ TNM stage } \\
\hline 2 & $4(50)$ & $4(50)$ & $0.593^{*}$ & $3(33)$ & $6(67)$ & $0.135^{*}$ & $6(40)$ & $9(60)$ & 0.293 & $5(63)$ & $3(37)$ & $0.337^{*}$ & $3(43)$ & $4(57)$ & $0.537^{*}$ & $5(63)$ & $3(37)$ & $0.408^{*}$ & $5(63)$ & $3(37)$ & $0.372^{*}$ \\
\hline 3 & $31(53)$ & $28(47)$ & & $35(59)$ & $24(41)$ & & $39(55)$ & $32(45)$ & & $27(47)$ & $30(53)$ & & $27(49)$ & $28(51)$ & & $29(51)$ & $28(49)$ & & $28(49)$ & $29(51)$ & \\
\hline Total & 35 & 32 & & 38 & 30 & & 45 & 41 & & 32 & 33 & & 30 & 32 & & 34 & 31 & & 33 & 32 & \\
\hline \multicolumn{22}{|l|}{ ER status } \\
\hline Negative & $18(49)$ & $19(51)$ & 0.718 & $20(53)$ & $18(47)$ & 0.435 & $23(52)$ & $21(48)$ & 0.844 & $16(46)$ & $19(54)$ & 0.467 & $15(43)$ & $20(57)$ & 0.218 & $21(60)$ & $14(40)$ & 0.187 & $15(43)$ & $20(57)$ & 0.185 \\
\hline Positive & $18(53)$ & $16(47)$ & & $21(62)$ & $13(38)$ & & $25(54)$ & $21(46)$ & & $18(55)$ & $15(45)$ & & $18(58)$ & $13(42)$ & & $15(44)$ & $19(66)$ & & $20(59)$ & $14(41)$ & \\
\hline Total & 36 & 35 & & 41 & 31 & & 48 & 42 & & 34 & 34 & & 33 & 33 & & 36 & 33 & & 35 & 34 & \\
\hline \multicolumn{22}{|l|}{ PgR status } \\
\hline Negative & $20(54)$ & $17(46)$ & 0.329 & $21(55)$ & $17(45)$ & 0.464 & $25(56)$ & $20(44)$ & 0.066 & $17(49)$ & $18(51)$ & 0.916 & $16(47)$ & $18(53)$ & 0.316 & $25(69)$ & $11(31)$ & 0.198 & $18(50)$ & $18(50)$ & 0.862 \\
\hline Positive & $9(41)$ & $13(59)$ & & $10(45)$ & $12(55)$ & & $11(34)$ & $21(66)$ & & $11(50)$ & $11(50)$ & & 7 (33) & $14(67)$ & & $11(52)$ & $10(48)$ & & $11(52)$ & $10(48)$ & \\
\hline Total & 29 & 30 & & 31 & 29 & & 36 & 41 & & 28 & 29 & & 23 & 32 & & 36 & 21 & & 29 & 28 & \\
\hline \multicolumn{22}{|l|}{ HER status } \\
\hline Negative & $17(43)$ & $23(57)$ & 0.458 & $20(48)$ & $22(52)$ & 0.174 & $29(52)$ & $27(48)$ & 0.635 & $18(45)$ & $22(55)$ & 0.107 & $15(38)$ & $24(62)$ & 0.116 & $24(60)$ & $16(40)$ & 0.677 & $21(54)$ & $18(46)$ & 0.647 \\
\hline Positive & $12(52)$ & $11(48)$ & & $15(65)$ & $8(35)$ & & $12(46)$ & $14(54)$ & & $14(67)$ & $7(33)$ & & $12(60)$ & $8(40)$ & & $12(55)$ & $10(45)$ & & $11(48)$ & $12(52)$ & \\
\hline Total & 29 & 34 & & 35 & 30 & & 41 & 41 & & 32 & 29 & & 27 & 32 & & 36 & 26 & & 32 & 30 & \\
\hline \multicolumn{22}{|c|}{ Pathological complete response } \\
\hline CR & $7(54)$ & $6(46)$ & 0.802 & $7(50)$ & $7(50)$ & 0.559 & $7(44)$ & $9(56)$ & 0.397 & $3(25)$ & $9(75)$ & $0.050^{*}$ & $6(46)$ & $7(54)$ & 0.757 & $10(77)$ & $3(23)$ & $0.045^{*}$ & $8(62)$ & $5(38)$ & 0.387 \\
\hline Non-CR & $29(50)$ & $29(50)$ & & $34(59)$ & $24(41)$ & & $41(55)$ & $33(45)$ & & $31(55)$ & $25(45)$ & & $27(51)$ & $26(49)$ & & $26(46)$ & $30(54)$ & & $27(48)$ & $29(52)$ & \\
\hline Total & 36 & 35 & & 41 & 31 & & 48 & 42 & & 34 & 34 & & 33 & 33 & & 36 & 33 & & 35 & 34 & \\
\hline \multicolumn{22}{|c|}{ Clinical complete response } \\
\hline CR & $15(56)$ & $12(44)$ & 0.522 & $14(50)$ & $14(50)$ & 0.342 & $13(43)$ & $17(57)$ & 0.202 & $16(64)$ & $9(36)$ & 0.078 & $15(60)$ & $10(40)$ & 0.205 & $16(59)$ & $11(41)$ & 0.345 & $16(59)$ & $11(41)$ & 0.256 \\
\hline Non-CR & $21(48)$ & $23(52)$ & & $27(61)$ & $17(39)$ & & $34(58)$ & $25(42)$ & & $18(42)$ & $25(58)$ & & $18(44)$ & $23(56)$ & & $20(48)$ & $22(52)$ & & $19(45)$ & $23(55)$ & \\
\hline Total & 36 & 35 & & 41 & 31 & & 47 & 42 & & 34 & 34 & & 33 & 33 & & 36 & 33 & & 35 & 34 & \\
\hline
\end{tabular}

Pearson's $\chi^{2}$ test of association values stated unless the frequency of observations in a cell was $<5$; therefore, Fisher's exact stated (indicated by *).

Statistically significant $P$-values are indicated by bold font. 
significance was determined using log rank. Cox proportional hazards model was used to test statistical independence and paired $t$-test for the relationship between pre- and post-tumour expression levels. Intraclass correlations were applied to determine the consistency, or conformity, between assessors using the continuous scores that were produced by each individual scoring independently from the same tissue sections. All differences were deemed statistically significant at the level of $P<0.05$.

\section{Results}

\section{Redox Proteins Expression and Clinicopathological Characteristics}

Table 1 shows the full clinicopathologic characteristics of the patient cohort that were assessable for each protein. In $\sim 80 \%$ of cases, the maximum risk of recurrence was within the first 2 years. Only 15 living cases $(15 \%)$ had a follow-up time $\leq 2$ years. The median age of patients was 51 with a range of 25-76 years. The assessment of protein expression was conducted with a high level of concordance between independent observers: thioredoxin 0.962, thioredoxin reductase 0.976, TxNIP 0.838, GST $\theta$ 0.930 , GST $\pi$ 0.973, catalase 0.964, MnSOD 0.916 . All proteins were assessed for cytoplasmic staining, with some granularity and heterogeneity between adjacent tumour cells, varying from weak to intense staining. Some occasional nuclear staining was observed for thioredoxin, thioredoxin reductase and GST $\pi$ but was not assessed. Figures 1 and 2 demonstrate the immunostaining pattern of the proteins. No expression of GST $\alpha$ was observed apart from in the liver sections that were used as positive
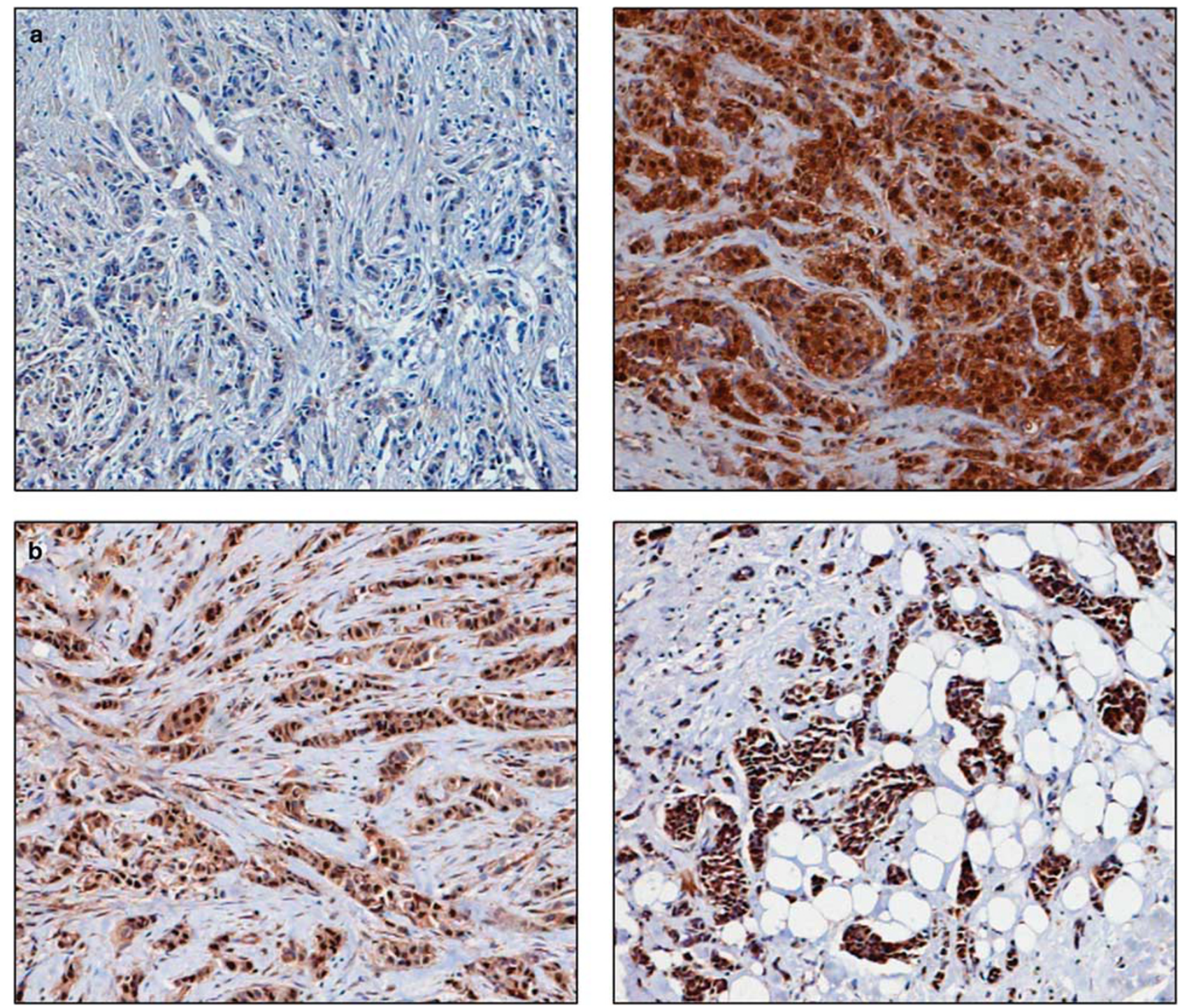

Figure 1 Photomicrographs of low (left panel) and high (right panel) immunohistochemical protein expression at $\times 10$ magnification (a) thioredoxin (b) thioredoxin reductase (c) thioredoxin interacting protein (d) manganese superoxide dismutase. Stain is $3,3^{\prime}-$ diaminobenzidine counterstained with haematoxylin. 

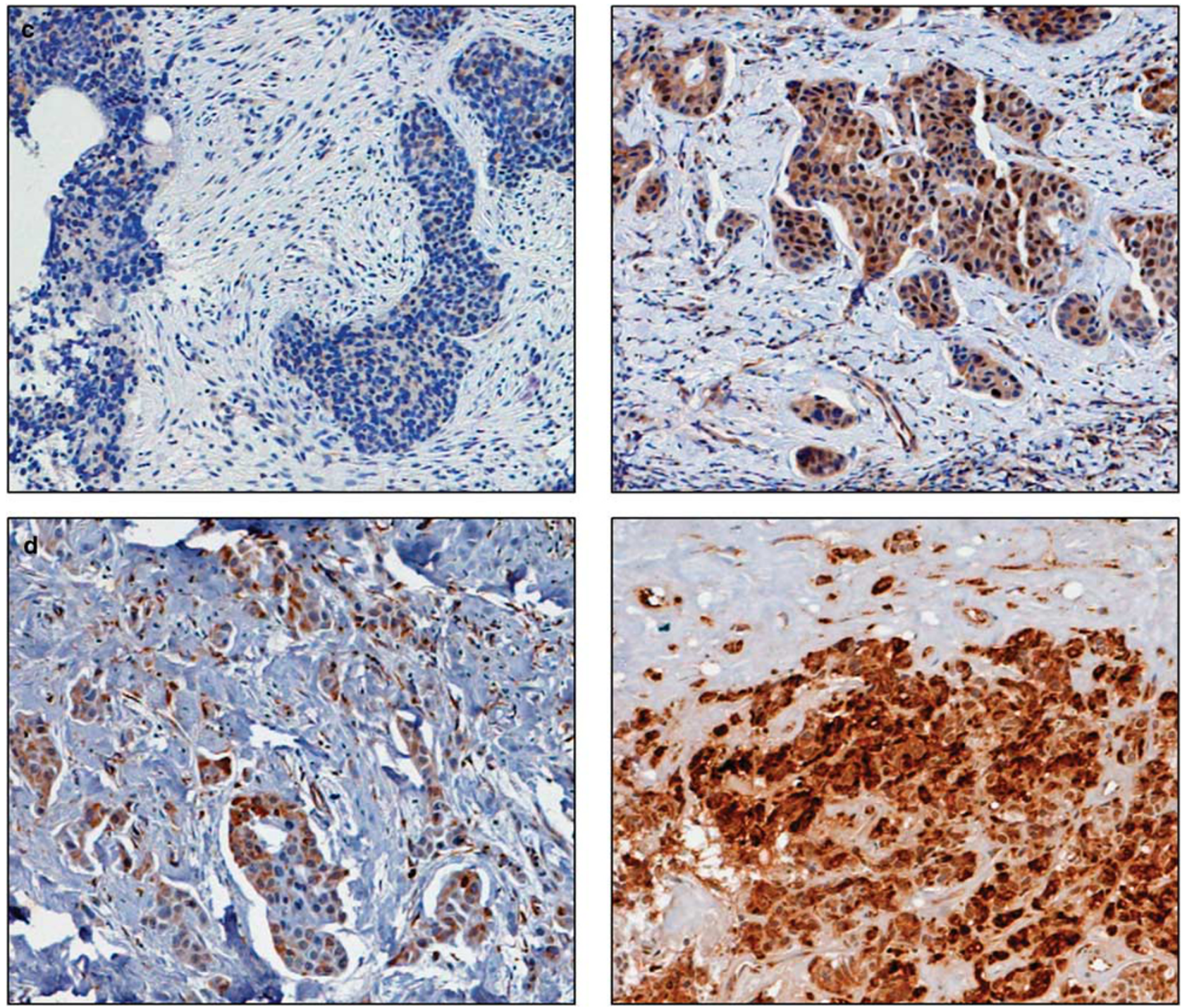

Figure 1 Continued.

controls (Figure 2d). The expression of redox proteins in the pre-chemotherapy samples was not associated with clinicopathologic characteristics, that is, TNM stage, histopathologic subtype, oestrogen receptor, HER2, progesterone receptor status or age (Table 1).

\section{Redox Protein Expression and Response}

Pathological complete response is the most reliable end point of response to neoadjuvant treatment. For this study, pathological complete response was analysed vs partial response, stable disease and progressed disease that were grouped due to the limited numbers in certain categories. Borderline associations were observed for GST $\pi\left(\chi^{2}=3.643\right.$, $\mathrm{df}=1, P=0.05)$ and catalase $\left(\chi^{2}=3.932, \mathrm{df}=1\right.$, $P=0.045)$ with pathological complete response in the pre-chemotherapy biopsy samples. From the cases that had completely responded, $75 \%$ (9/12) had high GST $\pi$ levels and $77 \%(10 / 13)$ a low expression of catalase. Thioredoxin $P=0.802$, thioredoxin reductase $P=0.559$, TxNIP $P=0.397$, GST $\theta$ $P=0.757$ and MnSOD $P=0.387$ showed no association with pathological complete response (Table 1).

Oestrogen receptor negative tumours are known to achieve a better pathological complete response ${ }^{12,13}$ and in this cohort, oestrogen receptor status was significantly associated with pathological complete response $\left(\chi^{2}=7.572, \mathrm{df}=1, P=0.005\right)$ with $82 \%$ (14/17) of responders being oestrogen receptor negative. Therefore, the combination of GST $\pi$ or catalase expression with oestrogen receptor status was assessed in the pre-chemotherapy biopsies vs pathological complete response. Data were grouped into four combinations, that is, oestrogen receptor negative with low redox protein expression, oestrogen receptor negative with high redox protein expression, oestrogen receptor positive with low redox protein expression 
and oestrogen receptor positive with high redox protein expression. In all, $67 \%$ (8/12) of complete responders had a high expression of GST $\pi$ in oestrogen receptor negative tumours $\left(\chi^{2}=11.024, \mathrm{df}=3, P=\right.$ 0.012). Analysing this category (ie, oestrogen receptor negative/GST $\pi$ high) against the other subgroups combined highlighted a strong significant association with pathological complete response $\left(\chi^{2}=10.853\right.$, $\mathrm{df}=1, P=0.002$ ). Catalase/oestrogen receptor combinations showed that the association of a low expression of catalase with oestrogen receptor negative was of interest in the complete responders $\left(\chi^{2}=4.147\right.$, $\mathrm{df}=1, P=0.042,53.8 \%$ cases $(7 / 13))$.

Redox protein expression was not associated with clinical complete response-TxNIP $P=0.202$, thioredoxin $P=0.522$, thioredoxin reductase $P=0.342$, GST $\theta P=0.205$, GST $\pi P=0.078$, catalase $P=0.345$,
MnSOD $P=0.256 \quad$ (Table 1). Clinical complete response was also analysed as complete response vs partial response, stable disease and progressed disease grouped.

\section{Redox Protein Expression and Survival}

The age of the patients $(\leq 40,40-60,>60)$ was significantly associated with distant metastasis-free survival $(P=0.032)$ with the $\leq 40$ age group showing good prognosis. The $\leq 40$ group also showed a significantly better overall survival $(P=0.04)$. However, it should be noted that this cohort is a relatively small and homogeneous population.

In the pre-chemotherapy biopsies, Figure 3a demonstrates that a high expression of TxNIP
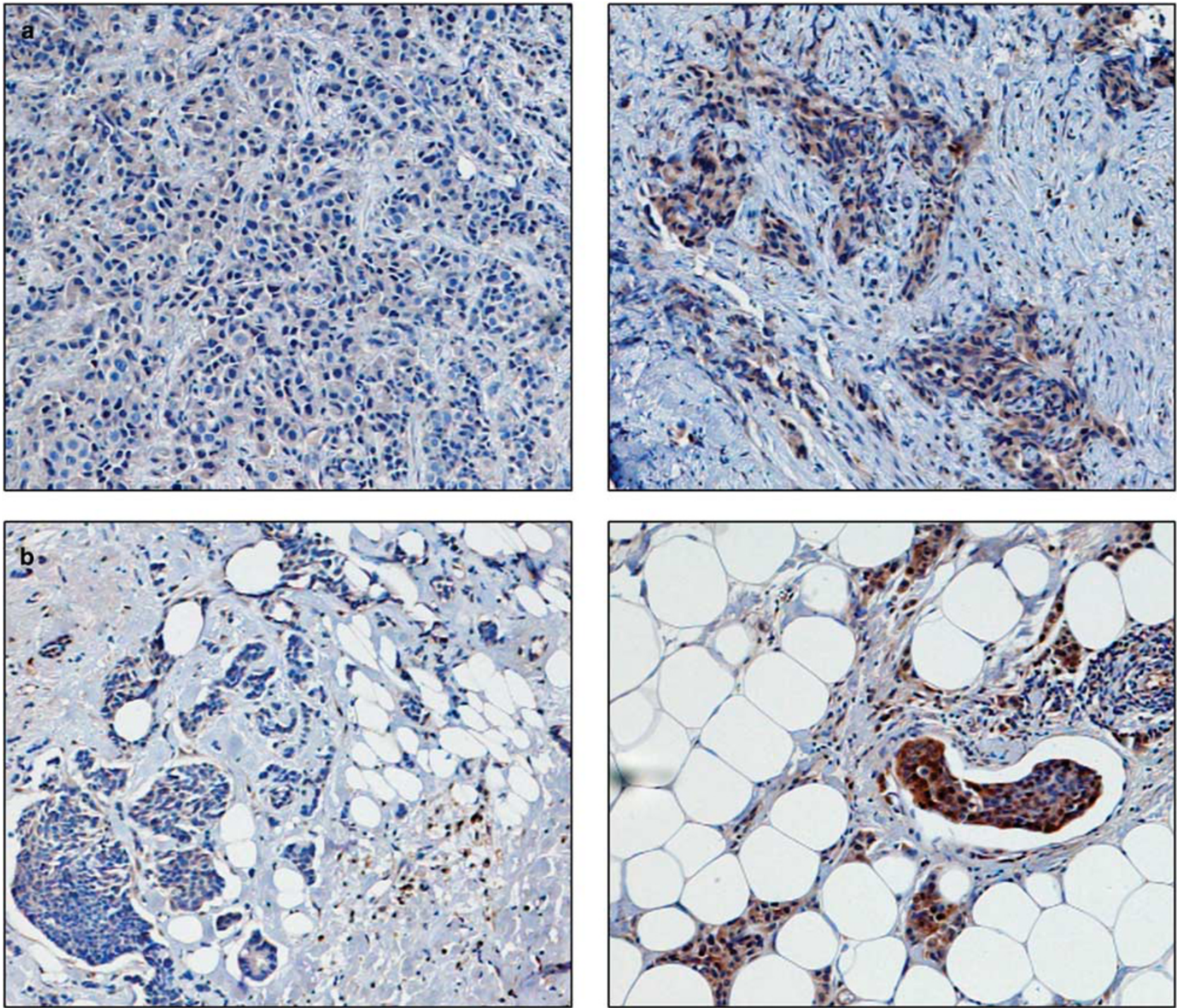

Figure 2 Photomicrographs of low (left panel) and high (right panel) immunohistochemical protein expression at $\times 10$ magnification (a) glutathione S-transferase $\theta$ (b) glutathione S-transferase $\pi$ (c) catalase. Positive control showing glutathione S-transferase $\alpha$ staining on liver sections (d) and (e) breast composite demonstrating absence of staining. Stain is 3,3'-diaminobenzidine counterstained with haematoxylin. 

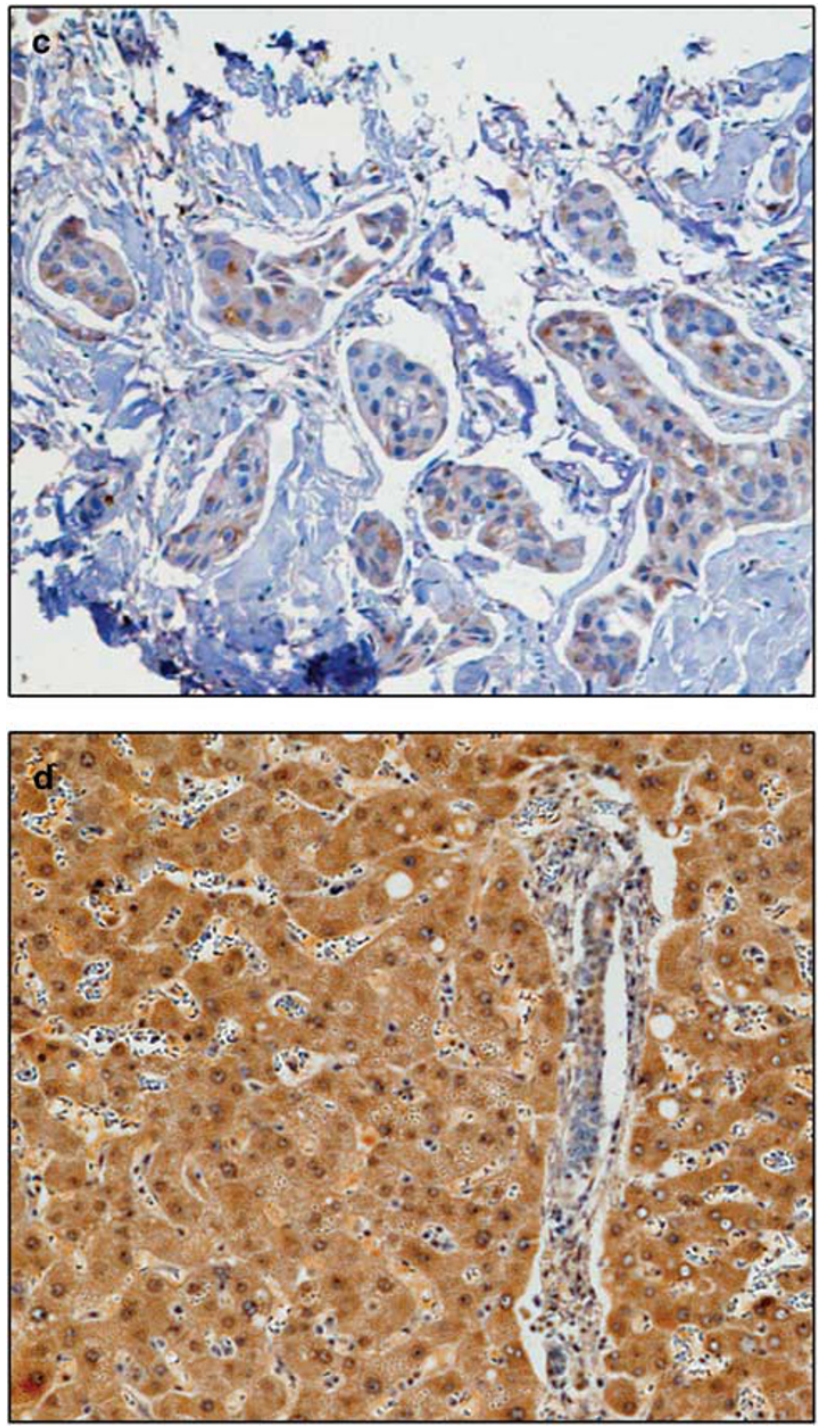

Figure 2 Continued.

$(P=0.021)$ and Figure $3 \mathrm{~b}$ demonstrates that a high expression of thioredoxin reductase $(P=0.021)$, was associated with distant metastasis-free survival. Multivariate analysis (Table 2) shows that TxNIP $(P=0.017$, hazard ratio $(\mathrm{HR})=0.3,95 \%$ confidence interval $(\mathrm{CI})=0.1-0.8)$ and thioredoxin reductase $(P=0.022, \mathrm{HR}=0.3,95 \% \mathrm{CI}=0.1-0.8)$ are independent factors. Distant metastasis-free survival showed no association with hormone receptor status using Kaplan-Meier/log rank analysis (oestrogen receptor $P=0.180$, HER2 $P=0.585$, progesterone receptor $P=0.892$ ) and is not known to be of prognostic value in this setting; therefore, no further statistical analysis was conducted incorporating redox protein expression.

In the pre-chemotherapy biopsies, Figure 4a shows that a high expression of TxNIP was associated with a better overall survival $(P=0.037)$. Multivariate analysis demonstrated that TxNIP is an independent prognostic factor $(P=0.014, \mathrm{HR}=0.2$,
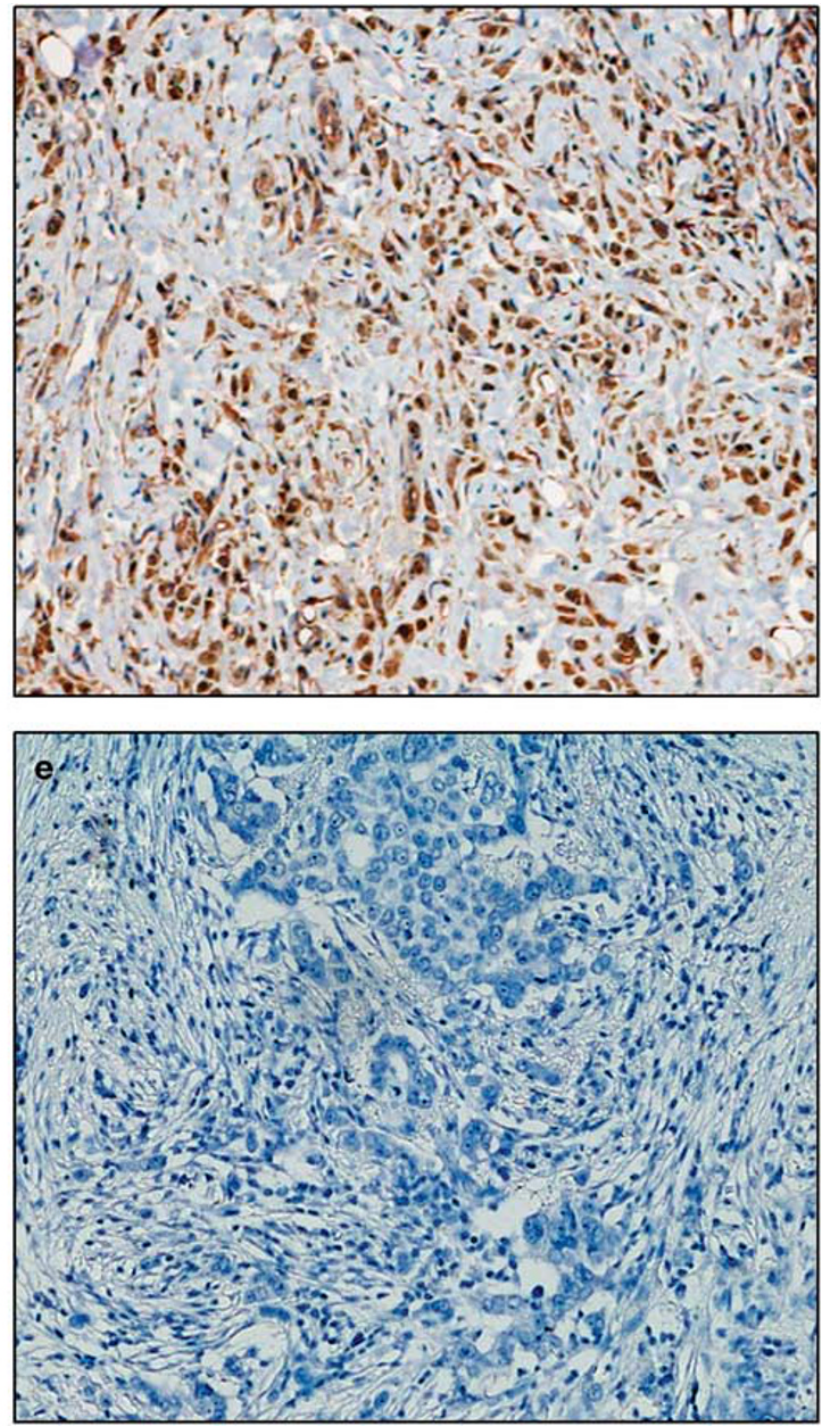

$95 \% \mathrm{CI}=0.1-0.7)$ and, of note, independent of oestrogen receptor status $(P=0.001, \mathrm{HR}=0.1,95 \%$ $\mathrm{CI}=0.0-0.3$ ) (Table 2).

Despite the better pathological complete response from oestrogen receptor negative tumours, surprisingly oestrogen receptor negative patients are known to have a worse overall survival, ${ }^{12,13}$ which was also observed in this cohort $(P=0.014)$ (Figure $4 \mathrm{~b}$ ). Therefore, TxNIP expression with oestrogen receptor status was analysed, using the same combinations as for pathological complete response. Oestrogen receptor negative/low TxNIP expression had a considerably worse prognosis $(P=0.00006)$ (Figure $4 c)$. Analysing this group against the remaining groups combined was highly significant $(P=0.000003)$ (Figure 4d) and was an independent prognostic factor $\quad(P=0.0003, \quad \mathrm{HR}=0.1, \quad 95 \% \quad \mathrm{CI}=0.0-0.4)$ (Table 2). Oestrogen receptor negative patients can therefore be notably stratified further using TxNIP expression. 


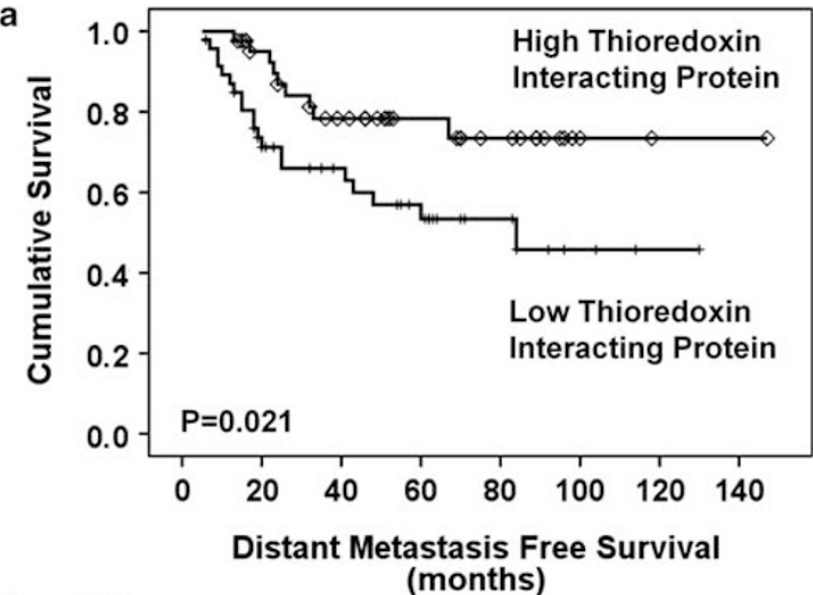

$\begin{array}{rllllllll}\text { No at Risk } & & & & & & & \\ \text { Low } & 47 & 29 & 22 & 15 & 8 & 3 & 1 & 0 \\ \text { High } & 42 & 35 & 25 & 16 & 11 & 2 & 1 & 1\end{array}$

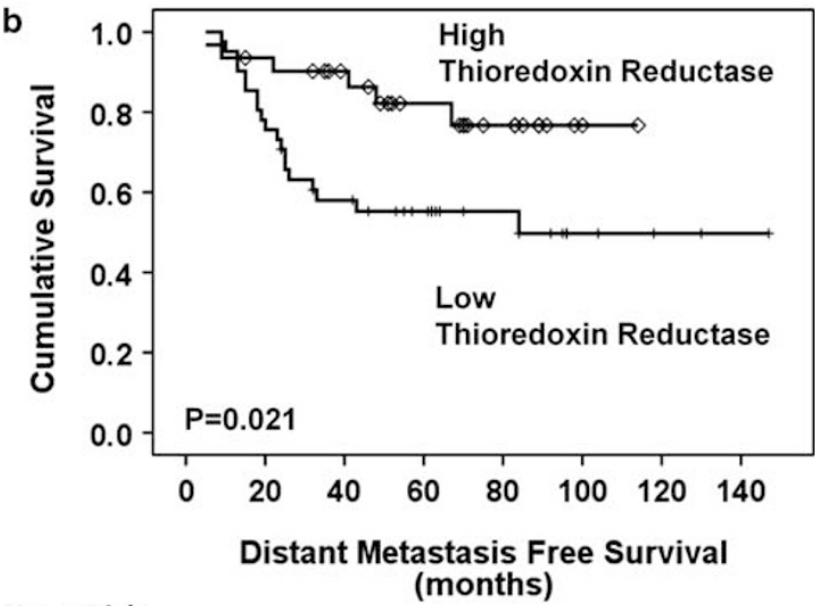

No at Risk

$\begin{array}{rrrrrrrrr}\text { Low } & 41 & 31 & 22 & 16 & 10 & 4 & 2 & 1 \\ \text { High } & 31 & 28 & 23 & 15 & 9 & 1 & 0 & 0\end{array}$

Figure 3 Kaplan-Meier distant metastasis-free survival curves. High thioredoxin interacting protein (a) and high thioredoxin reductase (b) correlate with a good prognosis $(P=0.021$, $P=0.021$ ).

\section{Comparison of Redox Expression Pre- and Post-Anthracycline-Based Chemotherapy}

A paired set of tumour samples, pre- and postchemotherapy, were available for certain patients and therefore changes in redox protein expression were evaluated. Thioredoxin $(n=41)$, TxNIP $(n=39)$, GST $\theta(n=43)$ and MnSOD $(n=20)$ all showed significant increases in expression levels after anthracycline-based chemotherapy $(P=0.00000002, P=0.006, P=0.023$ and $P=0.048$, respectively) (Figure 5). Although results point towards these pathways being activated by chemotherapy, the level of increase of these four redox proteins was not significant against clinical parameters such as pathological complete response, distant metastasis-free or overall survival. This was not unexpected due to the small sample size involved but this would warrant further investigation in a larger cohort and in serial biopsies after each chemotherapy cycle. Thioredoxin reductase $(n=31)$, GST $\pi(n=46)$ and catalase $(n=22)$ showed no significant change $(P=0.762, P=0.274$ and $P=0.214$, respectively).

\section{Discussion}

To our knowledge, this is the first study to examine a panel of redox proteins in a well-defined cohort of locally advanced primary breast cancer cases before receiving neoadjuvant anthracycline-based chemotherapy. Limited studies have utilised prebiopsy samples and the numbers are generally small due to the nature of the sample type. Results demonstrate that the expression of redox proteins in initial, pre-treatment, tumour specimens may be important prognostically and as determinants of response. The observed absence of expression of GST $\alpha$ was mirrored in two previous studies that reported very low expression in both normal and breast tumour tissues ${ }^{14}$ and decreased immunointensity in tumour compared with normal. ${ }^{15}$

High GST $\pi$ expression associated with a greater probability of pathological complete response and notably further stratified oestrogen receptor negative patients $(P=0.002)$. GST $\pi$ expression has been linked to oestrogen receptor status and also showed an inverse correlation, ${ }^{16-18}$ but this is the first report in pre-chemotherapy locally advanced primary breast cancer. Due to the nature of GST $\pi$ as a detoxification enzyme, studies have connected its high expression to multidrug resistance in various cancers $^{19,20}$ but although the literature related to GST $\pi$, anthracyclines and breast cancer is relatively consistent in vitro, the in vivo data are contradictory. In certain studies, a high GST $\pi$ expression was associated with a shorter distant metastasis-free and overall survival $^{21,22}$ whereas others had a better outcome. ${ }^{23,24}$ The current study saw no significance with distant metastasis-free or overall survival. In contrast, a low expression of catalase was associated with a greater incidence of pathological complete response $(P=0.045)$. Catalase functions to catalyse the decomposition of $\mathrm{H}_{2} \mathrm{O}_{2}$ to water and oxygen. When catalase expression is low, $\mathrm{H}_{2} \mathrm{O}_{2}$ formed by anthracyclines may be less effectively processed resulting in hydroxyl radicals and potentially tumour cell death, thus pathological complete response.

High expression of thioredoxin reductase was a prognostic factor for better distant metastasis-free survival $(P=0.022)$. Such results may appear to contradict the systems antioxidant function, but it has been shown that endogenous thioredoxin increases the redox cycling of anthracyclines and enhances their apoptotic potential. ${ }^{25}$ An increased 
Table 2 Multivariate Cox proportional hazards analysis for predictors of distant metastasis-free and overall survival in locally advanced primary breast cancer patients treated with neoadjuvant anthracycline-based chemotherapy

Multivariate analysis for distant metastasis-free survival

\begin{tabular}{|c|c|c|c|c|c|c|}
\hline & \multicolumn{3}{|c|}{ TXNIP } & \multicolumn{3}{|c|}{ Thioredoxin reductase } \\
\hline & Hazard ratio & $95 \% C I$ & Significance & Hazard ratio & $95 \% C I$ & Significance \\
\hline Protein & 0.3 & $0.1-0.8$ & $0.017^{*}$ & 0.3 & $0.1-0.8$ & $0.022^{*}$ \\
\hline ER & 0.1 & $0.0-0.5$ & $0.002^{*}$ & 0.2 & $0.1-0.7$ & $0.011^{*}$ \\
\hline HER2 & 1.5 & $0.6-4.2$ & 0.424 & 1.7 & $0.6-5.2$ & 0.327 \\
\hline PgR & 3.5 & $1.1-11.7$ & $0.038^{*}$ & 2.1 & $0.7-6.1$ & 0.166 \\
\hline TNM & 1.2 & $0.3-5.4$ & 0.837 & 1.7 & $0.2-14.6$ & 0.642 \\
\hline Age & 2.9 & $1.1-7.3$ & $0.027^{*}$ & 1.8 & $0.7-4.2$ & 0.206 \\
\hline
\end{tabular}

Multivariate analysis for overall survival

\begin{tabular}{|c|c|c|c|c|c|c|}
\hline & \multicolumn{3}{|c|}{$T \times N I P$} & \multicolumn{3}{|c|}{ TxNIP with ER status } \\
\hline & Hazard ratio & $95 \% C I$ & Significance & Hazard ratio & $95 \% C I$ & Significance \\
\hline Protein & 0.2 & $0.1-0.7$ & $0.014^{*}$ & 0.1 & $0.0-0.4$ & $0.0003^{*}$ \\
\hline ER & 0.1 & $0.0-0.3$ & $0.001^{*}$ & - & - & - \\
\hline HER2 & 0.4 & $0.1-2.1$ & 0.294 & 1.1 & $0.4-2.8$ & 0.920 \\
\hline PgR & 2.1 & $0.5-8.5$ & 0.288 & 2.3 & $0.8-6.7$ & 0.139 \\
\hline TNM & 0.4 & $0.1-2.0$ & 0.254 & 1.6 & $0.4-7.1$ & 0.553 \\
\hline Age & 3.0 & $1.1-8.3$ & $0.035^{*}$ & 2.6 & $1.1-6.2$ & $0.029^{*}$ \\
\hline
\end{tabular}

Abbreviation: CI, confidence interval.

*Statistically significant.
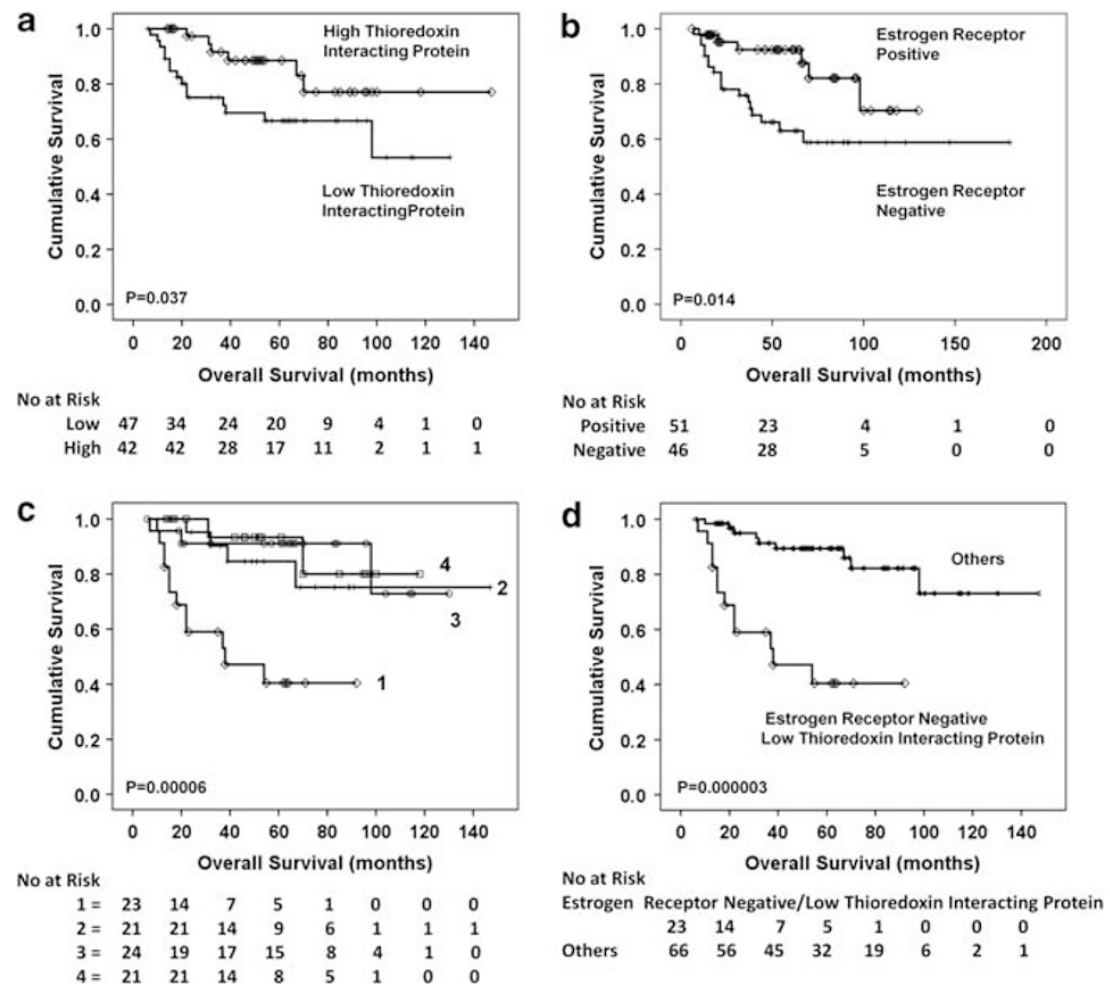

Figure 4 Kaplan-Meier overall survival curves. (a) A high expression of thioredoxin interacting protein is significantly associated with a better prognosis $(P=0.037)$. (b) Oestrogen receptor status is an independent predictive factor $(P=0.014$ in this cohort). Therefore, correlations were made between redox proteins and oestrogen receptor status by grouping patients: $1=$ oestrogen receptor negative with low redox expression, $2=$ oestrogen receptor negative with high redox expression, $3=$ oestrogen receptor positive with low redox expression, 4 = oestrogen receptor positive with high redox expression. (c) Oestrogen receptor negative cases with a low thioredoxin interacting protein expression had a considerably worse prognosis $(P=0.00006)$ (group 1$)$ and analysing this group against the others combined (d) was highly significant $(P=0.000003)$. 


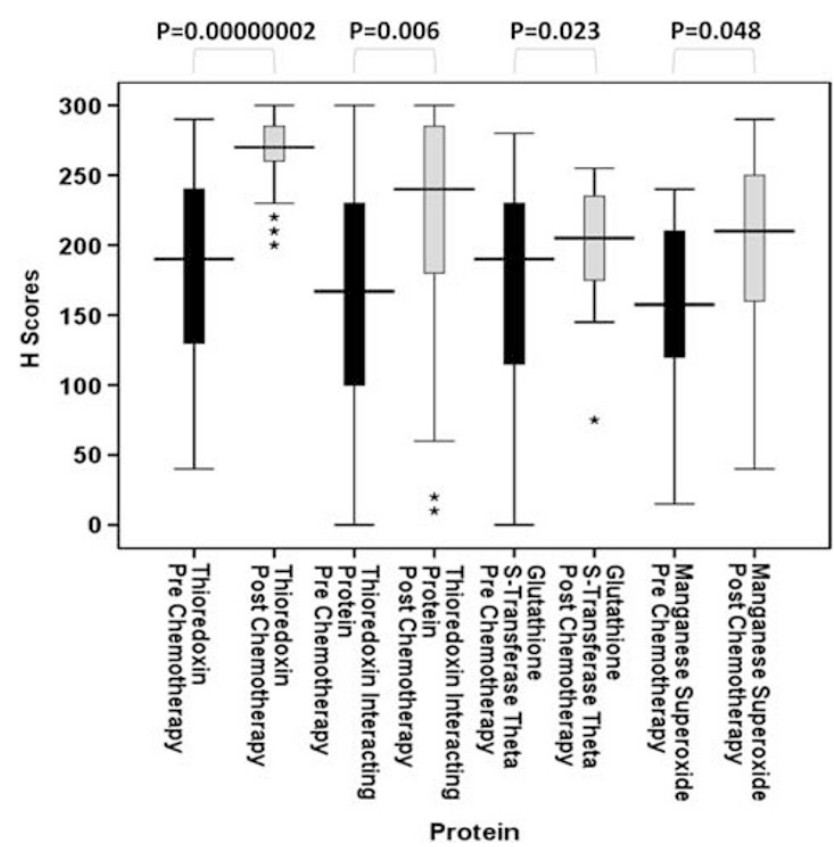

Figure 5 Stem and leaf plots of thioredoxin, thioredoxin interacting protein, glutathione S-transferase $\theta$ and manganese superoxide dismutase protein expression pre- and post-anthracycline-based chemotherapy. Figure demonstrates that significant increases in protein expression have occurred after chemotherapy treatment. ${ }^{*} P<0.05 ;{ }^{*} P<<0.01 ;{ }^{*}{ }^{*} P<0.001$.

expression of thioredoxin reductase would maintain thioredoxin in its reduced, active state.

In the present study, high expression of TxNIP was also a prognostic factor for a better distant metastasis-free $(P=0.017)$ and overall survival $(P=0.014)$. Strikingly though, TxNIP combined with oestrogen receptor status subdivided the oestrogen receptor negative cases into those with comparable prognosis to oestrogen receptor positive and those that had a poor outcome for overall survival $(P=0.000003)$. To our knowledge, this is the first study to examine the relationship between TxNIP in neoadjuvant locally advanced primary breast cancer cases. One study assessed RNA expression in breast cancer patients that had no treatment and found that a high level of TxNIP was significant for a better metastasis-free survival. ${ }^{26}$ TxNIP is a competitive inhibitor of thioredoxin. Overexpression of TxNIP inhibits proliferation of tumour cells, ${ }^{27}$ environmental conditions such as $\mathrm{H}_{2} \mathrm{O}_{2}$ can upregulate its expression ${ }^{28}$ and it is downregulated in a number of cancers. ${ }^{27,29}$ TxNIP can also function through alternative mechanisms such as Jun activating binding protein affecting its influence on p27 $7^{\text {kip } 1}$ [ref. 30] or via suppression of cell invasion/metastasis by association with the $\beta$ domain of von Hippel-Lindau protein. ${ }^{31}$ Importantly, both TxNIP and thioredoxin reductase were independent of oestrogen receptor. Despite reports of oestrogens altering expression of certain redox proteins, ${ }^{32,33}$ the authors have not found any reports of this occurring for TxNIP or thioredoxin reductase.
In summary, redox protein expression can determine response to therapy and survival outcomes in patients with locally advanced primary breast cancer subsequently treated with neoadjuvant chemotherapy. The high level of concordance between individual assessors suggests that assessment of redox protein expression may have clinical potential.

\section{Acknowledgement}

We gratefully acknowledge the Breast Cancer Campaign for funding this research.

\section{Disclosure/conflict of interest}

The authors declare no conflict of interest.

\section{References}

1 Muller I, Niethammer D, Bruchelt G. Anthracyclinederived chemotherapeutics in apoptosis and free radical cytotoxicity (review). Int J Mol Med 1998;1: 491-494.

2 Ravid A, Rocker D, Machlenkin A, et al. 1,25Dihydroxyvitamin D3 enhances the susceptibility of breast cancer cells to doxorubicin-induced oxidative damage. Cancer Res 1999;59:862-867.

3 Pennington JD, Wang TJ, Nguyen P, et al. Redoxsensitive signalling factors as a novel molecular targets for cancer therapy. Drug Resist Updat 2005;8:322-330.

4 Valko M, Leibfritz D, Moncol J, et al. Free radicals and antioxidants in normal physiological functions and human disease. Int J Biochem Cell Biol 2007;39:44-84.

5 Woolston CM, Deen S, Al-Attar A, et al. Redox protein expression predicts progression-free and overall survival in ovarian cancer patients treated by platinum-based chemotherapy. Free Radic Biol Med 2010; 49:1263-1272.

6 Woolston CM, Al-Attar A, Storr SJ, et al. Redox protein expression predicts radiotherapeutic response in earlystage invasive breast cancer patients. Int J Radiat Oncol Biol Phys 2011;79:1532-1540.

7 Toyokuni S, Okamoto K, Yodoi J, et al. Persistent oxidative stress in cancer. FEBS Lett 1995;358:1-3.

8 Behrend L, Henderson G, Zwacka RM. Reactive oxygen species in oncogenic transformation. Biochem Soc Trans 2003;31:1441-1444.

9 Mcshane LM, Altman DG, Sauerbrei W, et al. Reporting recommendations for tumor marker prognostic studies (REMARK). Breast Cancer Res Treat 2006;100:229-235.

10 Park JO, Lee SI, Song SY, et al. Measuring response in solid tumors: comparison of RECIST and WHO response criteria. Jpn J Clin Oncol 2003;33:533-537.

11 Chevallier B, Roche H, Olivier JP, et al. Inflammatory breast cancer. Pilot study of intensive induction chemotherapy (FEC-HD) results in a high histologic response rate. Am J Clin Oncol 1993;16:16223-16228.

12 Ring AE, Smith IE, Ashley S, et al. Oestrogen receptor status, pathological complete response and prognosis in patients receiving neoadjuvant chemotherapy for early breast cancer. B J Cancer 2004;91:2012-2017. 
13 Kuerer HM, Newman LA, Smith TL, et al. Clinical course of breast cancer patients with complete pathologic primary tumor and axillary lymph node response to doxorubicin-based neoadjuvant chemotherapy. J Clin Oncol 1999;17:460-469.

14 Forrester LM, Hayes JD, Millis R, et al. Expression of glutathione S-transferases and cytochrome P450 in normal and tumor breast tissue. Carcinogenesis 1990;11:2163-2170.

15 Alpert LC, Schecter RL, Berry DA, et al. Relation of glutathione $\mathrm{S}$-transferase $\alpha$ and $\mu$ isoforms to response to therapy in human breast cancer. Clin Cancer Res 1997;3:661-667.

16 Howie AF, Miller WR, Hawkins RA, et al. Expression of glutathione S-transferase B1, B2, Mu and Pi in breast cancers and their relationship to oestrogen receptor status. Br J Cancer 1989;60:834-837.

17 Montano MM, Deng H, Liu M, et al. Transcriptional regulation by the estrogen receptor of antioxidative stress enzymes and its functional implications. Oncogene 2004;23:2442-2453.

18 Moscow JA, Townsend AJ, Goldsmith ME, et al. Isolation of the human anionic glutathione S-transferase cDNA and the relation of its gene expression to estrogen-receptor content in primary breast cancer. Proc Natl Acad Sci USA 1988;85:6518-6522.

19 Nakanishi Y, Kawasaki M, Bai F, et al. Expression of p53 and glutathione S-transferase-pi relates to clinical drug resistance in non-small cell lung cancer. Oncology 1999;57:318-323.

20 Mayr D, Pannekamp U, Baretton GB, et al. Immunohistochemical analysis of drug resistance-associated proteins in ovarian carcinomas. Pathol Res Pract 2000;196:469-475.

21 Gilbert L, Elwood LJ, Merino M, et al. A pilot study of pi-class glutathione S-transferase expression in breast cancer: correlation with estrogen receptor expression and prognosis in node-negative breast cancer. J Clin Oncol 1993;11:49-58.

22 Huang J, Tan P-H, Thiyagarajan J, et al. Prognostic significance of glutathione S-transferase-pi in invasive breast cancer. Mod Pathol 2003;16:558-565.

23 Arun BK, Granville LA, Yin G, et al. Glutathiones-transferase-pi expression in early breast cancer: association with outcome and response to chemotherapy. Cancer Invest 2010;28:554-559.
24 Moureau-Zabotto L, Ricci S, Lefranc JP, et al. Prognostic impact of multidrug resistance gene expression on the management of breast cancer in the context of adjuvant therapy based on a series of 171 patients. Br J Cancer 2006;27:473-480.

25 Ravi D, Muniyappa H, Das KC. Endogenous thioredoxin is required for redox cycling of anthracyclines and p53-dependent apoptosis in cancer cells. J Biol Chem 2005;280:40084-40096.

26 Cadenas C, Franckenstein D, Schmidt M, et al. Role of thioredoxin reductase 1 and thioredoxin interacting protein in prognosis of breast cancer. Breast Cancer Res 2010;12:R44.

27 Han SH, Jeon JH, Ju HR, et al. VDUP1 upregulated by TGF-beta1 and 1,25-dihydorxyvitamin D3 inhibits tumor cell growth by blocking cell-cycle progression. Oncogene 2003;22:4035-4046.

28 Junn E, Han SH, Im JY, et al. Vitamin D3 up-regulated protein 1 mediates oxidative stress via suppressing the thioredoxin function. J Immunol 2000;164:6287-6295.

29 Butler LM, Zhou X, Xu WS, et al. The histone deacetylase inhibitor SAHA arrests cancer cell growth, up-regulates thioredoxin-binding protein-2, and down-regulates thioredoxin. Proc Natl Acad Sci USA 2002;99:11700-11705.

30 Jeon JH, Lee KN, Hwang CY, et al. Tumor suppressor VDUP1 increases p27(kip1) stability by inhibiting JAB1. Cancer Res 2005;65:4485-4489.

31 Shin D, Jeon JH, Jeong M, et al. VDUP1 mediates nuclear export of HIF1alpha via CRM1-dependent pathway. Biochim Biophys Acta 2008;1783:838-848.

32 Mobley JA, Brueggemeier RW. Estrogen receptormediated regulation of oxidative stress and DNA damage in breast cancer. Carcinogenesis 2004;25:3-9.

33 Mense SM, Remotti F, Bhan A, et al. Estrogen-induced breast cancer: alterations in breast morphology and oxidative stress as a function of estrogen exposure. Toxicol Appl Pharmacol 2008;232:78-85.

This work is licensed under the Creative Commons Attribution-NonCommercial-
No Derivative Works 3.0 Unported License. To view a copy of this license, visit http://creativecommons. org/licenses/by-nc-nd/3.0/ 